\title{
Physiological quality of the seeds of common bean cultivars grown in different phosphorus levels and growing seasons
}

\section{Qualidade fisiológica de sementes de cultivares de feijão carioca cultivadas sob diferentes doses de fósforo e épocas de cultivo}

\author{
Claudemir Zucareli ${ }^{1}$; Cristian Rafael Brzezinski²; \\ Flávia Werner²; Julia Abati²; João Nakagawa ${ }^{3}$
}

\begin{abstract}
The use of appropriate management practices, such as sowing and fertilizing, associated with the use of promising genotypes are strategies for obtaining bean seeds of high quality. The aim of this study was to evaluate the physiological quality of cultivars of common bean seeds produced in two growing seasons under different phosphorus levels. The experimental design was completely randomized in a factorial design of $2 \times 2 \times 6$, with four replications. We evaluated two common bean cultivars ('IAC Carioca Precoce' and 'IAC Carioca Tybatã'), two planting seasons of common beans (rainy season and dry season), and six rates of phosphorus fertilization $\left(0,30,60,90,120\right.$, and $150 \mathrm{~kg} \mathrm{ha}^{-1}$ of $\mathrm{P}_{2} \mathrm{O}_{5}$ ) applied to the planting rows, using triple super phosphate as the source of P. Seed quality was evaluated by testing the water content, germination, first account of the germination test, accelerated aging test and the water content after the test, electrical conductivity, and seedling emergence in the field. Data were subjected to analysis of variance and the means of cultivars and growing seasons were compared using Tukey's test at 5\% probability. Regression analysis was performed for phosphorus levels. Seeds of 'IAC Carioca Precoce' produced during the rainy season showed higher germination. In the dry season, the highest seedling emergence in the field was recorded for 'IAC Carioca Tybatã'. Common bean cultivation provided seeds with higher germination and vigor in the dry season than in the rainy season. The accelerated aging test showed that when phosphorus was applied in the planting rows, the vigor of common bean seed was enhanced, with a better response to higher doses when cultivated in the dry season.
\end{abstract}

Key words: Dry cultivation. Germination. Phaseolus vulgaris L. Vigor. Water cultivation.

\section{Resumo}

A utilização de práticas de manejo adequadas, como época de semeadura e adubação, associados ao uso de genótipos promissores, são estratégias para a obtenção de sementes de feijão de elevada qualidade. O objetivo do trabalho foi avaliar a qualidade fisiológica de sementes de cultivares de feijão carioca produzidas em duas épocas de cultivo com diferentes doses de fósforo. O delineamento experimental foi inteiramente casualizado, em esquema fatorial $2 \times 2 \times 6$, com quatro repetições. Foram avaliados duas cultivares de feijão carioca ('IAC Carioca Tybatã' e 'IAC Carioca Precoce'), duas épocas de cultivo de feijão (época das águas e da seca) e seis doses de fósforo $\left(0,30,60,90,120\right.$, e $150 \mathrm{~kg} \mathrm{ha}^{-1} \mathrm{de}$

\footnotetext{
${ }^{1}$ Prof. Dr., Universidade Estadual de Londrina, Departamento de Agronomia, Centro de Ciências Agrárias, CCA/UEL, Londrina, PR, Brasil. E-mail: claudemircca@uel.br

2 Discentes, Curso de Doutorado em Agronomia, UEL/CCA, Londrina, PR, Brasil. E-mail: cristian_brzezinski@yahoo.com.br; flawerner6@gmail.com; juliaabati@yahoo.com.br

3 Prof., Universidade Estadual Paulista Júlio de Mesquita Filho, Departamento de Produção Vegetal, UNESP, Botucatu, SP, Brasil. E-mail: secdamv@fc.unesp.br

* Author for correspondence
} 
$\mathrm{P}_{2} \mathrm{O}_{5}$ ) aplicadas no sulco de semeadura, utilizando como fonte o superfosfato triplo. A qualidade das sementes foi avaliada pelos seguintes testes: teor de água, germinação e primeira contagem do teste de germinação, envelhecimento acelerado e teor de água após o teste, condutividade elétrica e emergência de plântulas em campo. Os dados foram submetidos à análise de variância e as médias das cultivares e épocas de cultivo comparadas pelo teste de Tukey, a 5\% de probabilidade e as doses de fósforo foram analisadas através de regressão polinomial. Sementes da cultivar 'IAC Carioca precoce' produzidas na época das águas apresentam maior germinação, e na época da seca, maior emergência de plântulas em campo em relação a cultivar 'IAC Carioca Tybatã'. O cultivo de feijão carioca na época da seca proporciona sementes com maior germinação e vigor em relação à época das águas. $\mathrm{O}$ fósforo aplicado no sulco de semeadura favorece o vigor das sementes de feijão carioca, pelo teste de envelhecimento acelerado, com resposta a maiores doses no cultivo da seca.

Palavras-chave: Cultivo das águas. Cultivo da seca. Germinação. Phaseolus vulgaris L. Vigor.

\section{Introduction}

The common bean (Phaseolus vulgaris L.) is one of the most highly relevant crops, socially and economically, in Brazilian agriculture. The country is one of the largest producers and consumers worldwide of this legume, which is a source of protein, iron, zinc, calcium, magnesium, carbohydrates, fiber, and vitamins (CAVALCANTIMATA et al., 2012; MELO FILHO et al., 2011).

In Brazil, the carioca bean variety is consumed the most and is produced over three growing seasons (rainy, dry and winter), with a greater emphasis on area and production in the rainy and dry seasons. The area under cultivation and the production differ depending on the weather conditions. In the rainy season, sowing is concentrated in the months of August to October, at the beginning of the rainy season, favoring the availability of water throughout the crop cycle. In the dry season, sowing is carried out between January and April, at the end of the rainy season, when temperatures are higher, but water availability is less during the development of the crop (EMBRAPA, 2012). However, low yields are frequently observed in both these cultivation periods, due to the association of several factors such as low technological level employed, climate fluctuations, exhaustion of nutrients and soil resources (ZUCARELI et al., 2006; 2011), and use of low quality seeds (BARBOSA; GONZAGA, 2012).

Good quality seeds possess genetic, physical, physiological, and sanitary attributes that aim at ensuring good agronomic performance and, consequently, high yields. Of these, physiological quality is one of the more important attributes. This is because it is related to the ability of the seed to play its vital functions, characterized by longevity, germination percentage and vigor, providing rapid and uniform emergence, yielding seedlings with increased tolerance to environmental adversity and more uniform maturity of the crop (DUTRA et al., 2012; FRANÇA NETO et al., 2010; MARCOS FILHO, 2015).

The physiological attributes are influenced by the environment in which the seed was produced and by procedures followed during the stages of sowing, growth and development of plants, and during the harvest and post-harvest stages of the crop (TOLEDO et al., 2009). Another factor is the appropriate choice of cultivars, since quality can vary according to the soil and climatic requirements of the genotype, with the periods of cultivation, and the application of management techniques such as chemical fertilization. According to Carvalho and Nakagawa (2012), some nutrients such as nitrogen, phosphorus, calcium, magnesium, boron, and zinc, besides their doses provided to the plants, can positively affect the quality of seeds.

Among the essential nutrients, phosphorus plays an important role in various plant processes, such as photosynthesis, sugar metabolism, storage and transfer of energy, and cell division and expansion. It acts as a promoter of root development and plant growth, and is responsible for the increased efficiency of water use by plants and aids in the assimilation and utilization of other nutrients 
available in the soil (MALAVOLTA, 2006), thus affecting the physiological quality of seeds (SILVA et al., 2003).

However, in tropical regions, phosphorus displays a higher nutritional limitation to the development of crops, due to the high fixation of this nutrient to mineralogical components of the soil, thus presenting very low levels of soluble phosphorus (i.e. the phosphorus available to the plant). Thus, it is necessary to supplement fertilization to meet the need of plants in this nutrient (SOUZA et al., 2006).

In studies conducted to evaluate the effect of phosphorus content on seed quality of 19 common bean cultivars, Oliveira et al. (2014) observed that the highest dose of phosphorus (150 kg ha-1) resulted in an increase in the germination and seed mass of 11 cultivars. Carvalho et al. (2015) found that the provision of phosphorus, regardless of the form of application, improves the physiological quality of soybean seeds. Guerra et al. (2006) also found that phosphorus applied at the time of sowing increased the vigor, germination, and seedling emergence potential of crops in the field. However, Batistella Filho et al. (2013) found that phosphorus fertilization increased the productivity and seed mass for soybean, but did not affect physiological quality. Similar results were observed by Salum et al. (2008), who reported that the physiological quality of seeds was favored neither by the phosphorus content in the seed nor its availability in the soil.

Thus, information regarding the effect of fertilization on seed quality of carioca beans can assist in decision-making on the adequate dose of phosphorus that should be provided to the plants, depending on the cultivar and growing season. Given this background, the objective of this work was to evaluate the physiological quality of seeds of carioca bean cultivars produced in two growing seasons, and fertilized with different doses of phosphorus.

\section{Material and Methods}

The present study was carried out as two experiments, (i) in the field, and (ii) in the laboratory located in the Faculty of Agricultural Sciences of the Botucatu Campus - UNESP, at $22^{\circ} 45^{\prime} \mathrm{S}$, and $48^{\circ} 34^{\prime} \mathrm{W}$, and an altitude of $750 \mathrm{~m}$. According to the Köppen classification, the climate of the region is termed as Cwa (humid subtropical climate, mesothermal with drought in the winter period).

The weather data were obtained from the meteorological station of the Department of Natural Resources - Environmental Science, belonging to the Faculty of Agricultural Sciences of the Botucatu Campus - UNESP, located next to the experimental plots. The rainfall and average daily temperature data for the cultivation period in the rainy and dry season are presented in Figure 1.

The soil of the experimental area was identified as a dystrophic red latosol (SANTOS et al., 2006), analyzed at the $0-20 \mathrm{~cm}$ layer, in accordance with the methodology of Raij et al. (2001) (Table 1).

The experimental design adopted in the field was randomized blocks with four replications in a factorial $2 \times 2 \times 6$ scheme. The treatments were composed of two common Carioca bean cultivars ('IAC Carioca Tybatã' and 'IAC Carioca Precoce'), two growing seasons (rainy and dry) and six doses of phosphorus $\left(0,30,60,90,120\right.$ and $150 \mathrm{~kg} \mathrm{ha}^{-1}$ of $\mathrm{P}_{2} \mathrm{O}_{5}$ ), using triple superphosphate as a source, applied in the planting furrow. The management system used was conventional. The soil preparation involved one plowing and two harrows, and was limed two months before sowing.

The plots were composed of six rows, $5 \mathrm{~m}$ in length, spaced $0.5 \mathrm{~m}$ apart, and totaling $12.5 \mathrm{~m}^{2}$. The area consisted of four central lines, totaling 7.5 $\mathrm{m}^{2}$. The seedling density was 240,000 plants $\mathrm{ha}^{-1}$. At the time of sowing, $10 \mathrm{~kg} \mathrm{ha}^{-1}$ of $\mathrm{K}_{2} \mathrm{O}$ in the form of potassium chloride and $10 \mathrm{~kg} \mathrm{ha}^{-1}$ of $\mathrm{N}$ in the form of urea were applied. These were calculated based on chemical analysis of the soil. Further, $60 \mathrm{~kg}$ $\mathrm{ha}^{-1} \mathrm{~N}$, in the form of urea was applied as coverage fertilizer. This was applied twice, once at 15 days and again at 30 days after seedling emergence. 
Figure 1. Crop cycle, rainfall $(\mathrm{mm})$ and average air temperature $\left({ }^{\circ} \mathrm{C}\right)$ during the duration of the experiment for the production of seeds of cultivars 'IAC Carioca Precoce' (P) and 'IAC Carioca Tybatã' (T), grown in rainy and dry seasons. (S: Seedling and H: Harvest).
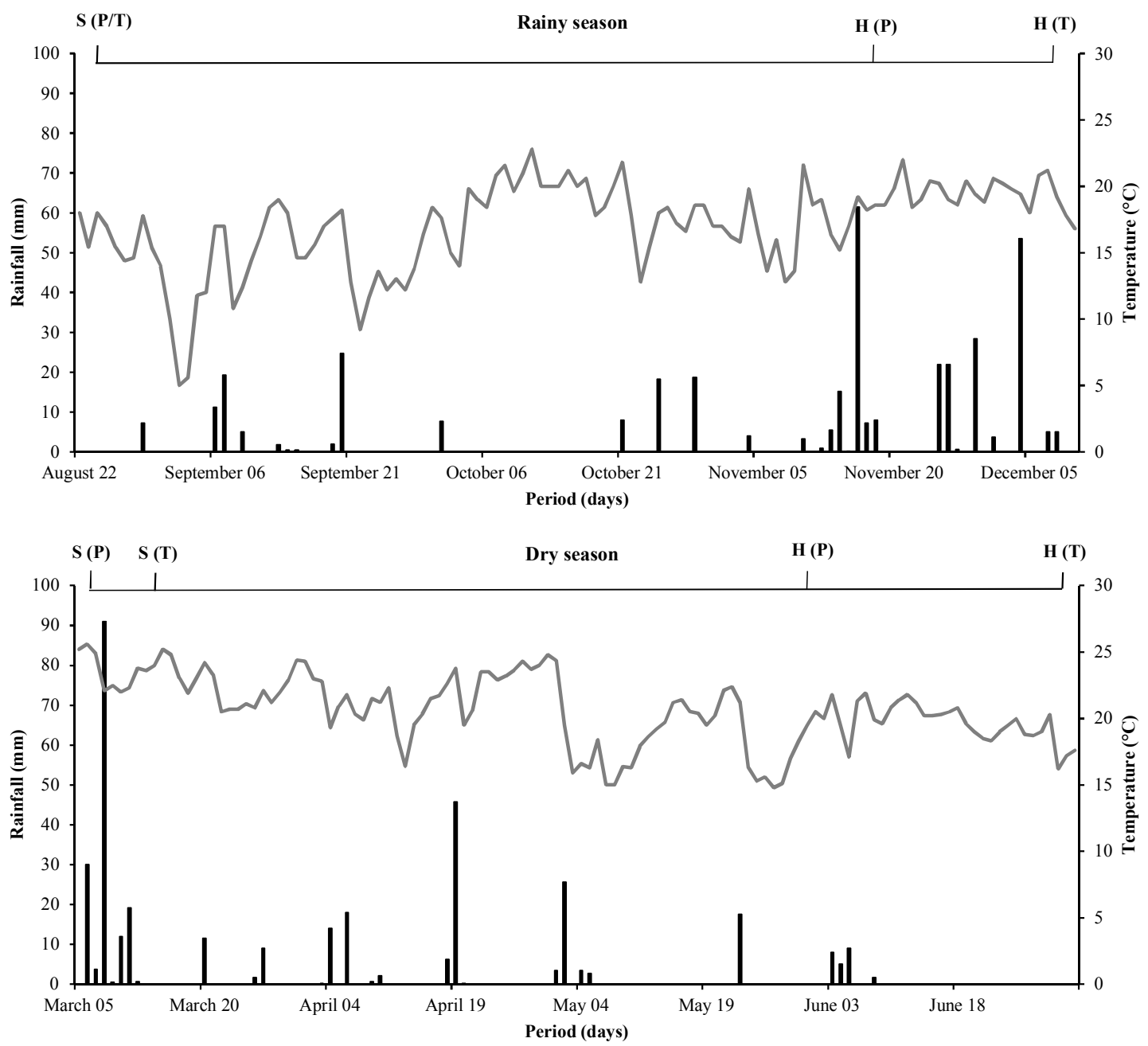

Table 1. Soil chemical attributes of the experimental area, analyzed using soil from the $0-20 \mathrm{~cm}$ depth layer, during the rainy and dry season.

\begin{tabular}{|c|c|c|c|c|c|c|c|c|c|c|c|c|c|}
\hline \multicolumn{14}{|c|}{ Rainy season } \\
\hline $\mathrm{pH}$ & $\mathrm{H}+\mathrm{Al}$ & $\mathrm{Mg}$ & $\mathrm{K}$ & $\mathrm{Ca}$ & SB & $\mathrm{CEC}^{1}$ & $\mathrm{P}$ & $\mathrm{Cu}$ & $\mathrm{Fe}$ & $\mathrm{Mn}$ & $\mathrm{Zn}$ & $\mathrm{OC}^{2}$ & $\mathrm{~V}^{3}$ \\
\hline $\mathrm{CaCl}_{2}$ & -------- & ----- & $\mathrm{mol}$ & $n^{-3}--$ & & --- & --- & ----1 & $\mathrm{dm}^{-3}$ & & -- & $\mathrm{g} \mathrm{dm}^{-3}$ & $\%$ \\
\hline 4.8 & 31.0 & 10.0 & 3.5 & 23.0 & 36.0 & 67.0 & 6.0 & 9.7 & 14.0 & 35.6 & 1.7 & 24.0 & 54.0 \\
\hline \multicolumn{14}{|c|}{ Dry season } \\
\hline 4.5 & 34.0 & 6.0 & 4.5 & 20.0 & 30.0 & 64.0 & 4.0 & 10.2 & 15.0 & 42.3 & 1.7 & 24.0 & 47.0 \\
\hline
\end{tabular}

${ }^{1} \mathrm{CEC}$ : cation exchange capacity at $\mathrm{pH}$ 7.0. ${ }^{2} \mathrm{OC}$ : organic carbon. ${ }^{3} \mathrm{~V}$ : base saturation. 
After being harvested and cleaned, the seeds of the four plots of each treatment were placed in multilayer paper bags, forming a composite sample, and stored in a dry chamber at a relative humidity of $30 \%$ and a temperature of $20^{\circ} \mathrm{C}$. Then, four subsamples of the composite sample for each treatment were taken for determining specific parameters to evaluate physiological quality of the seeds. This was undertaken in the Seed Analysis Laboratory of the Department of Agronomy at the State University of Londrina - UEL, Londrina, Paraná.

The experiment in the laboratory was a completely randomized block design, with four replications in a factorial $2 \times 2 \times 6$ scheme, consisting of the same factors used in the experimental field design. The following variables were evaluated in this experiment:

Water content was determined in an oven set at $105 \pm 3{ }^{\circ} \mathrm{C}$ for 24 hours, following the Rules for Seed Analysis (BRASIL, 2009).

Germination tests were performed with two subsamples of 50 seeds per repetition, totaling 400 seeds per treatment. The seeds were distributed on rolls of germitest paper towel moistened with distilled water with 2.5 times the mass of the dry paper and kept in a germinator-type growth chamber at a temperature of $25^{\circ} \mathrm{C}$. The count of normal seedlings was performed at nine days, again following the Rules for Seed Analysis (BRASIL, 2009).

The first count of germination test was conducted in conjunction with the germination test, by calculating the percentage of normal seedlings five days after the initiation of the test.

Accelerated aging and moisture content after aging were evaluated using two subsamples of 65 seeds per replication. These were placed evenly in a single layer in plastic boxes (gerbox) fitted with a mesh, containing $40 \mathrm{~mL}$ of distilled water at the bottom and maintained for a period of $72 \mathrm{~h}$ in a water jacketed chamber at $42{ }^{\circ} \mathrm{C}$ (MARCOS FILHO, 1999). After this step, the water content of two replications of 15 seeds each was determined, and the germination test was conducted with two replications of 50 seeds each, totaling 400 seeds per treatment. At five days after the installation of the test, the normal seedlings were counted and the results were expressed as a percentage.

Electrical conductivity was calculated using the mass conductivity method, with two replications of 50 seeds each, totaling 400 seeds per treatment. The weight of each sample was obtained using a digital scale with a precision of 0.01 . The seeds were then placed in plastic cups containing $75 \mathrm{~mL}$ of deionized water, and allowed to soak. These were then placed in a germination chamber, for 24 hours at a controlled temperature of $25{ }^{\circ} \mathrm{C}$ (VIEIRA; KRZYZANOWSKI, 1999). After this step, the electrical conductivity of seeds was determined with the aid of a bench conductivity digital meter, model DM-32 ${ }^{\circledR}$, and the results were expressed in $\mu \mathrm{S} \mathrm{cm} \mathrm{g}^{-1} \mathrm{~g}^{-1}$ of seeds.

Seedling emergence in the field were evaluated using four replications of 100 seeds for each treatment, sown in furrows of approximately $2 \mathrm{~cm}$ depth and $2.5 \mathrm{~m}$ in length, irrigated when needed. At 14 days after sowing, the normal seedlings that had emerged were counted and the results expressed as a percentage.

The data obtained were analyzed for normality and homoscedasticity using the Shapiro-Wilk and Hartley tests, respectively, which indicated the need for transformation. Analysis of variance was performed and the means of the cultivars and growing seasons were compared by the Tukey test at 5\% significance. Regression analysis was performed for the doses of phosphorus.

\section{Results and Discussion}

The summary of the analysis of variance and the mean values found for the isolated effects of cultivar and growing seasons are presented in Table 2. There was no interaction between the three factors studied (cultivars $\times$ growing seasons $\times$ doses of phosphorus) for any of the variables analyzed. 
Table 2. Summary of the analysis of variance and mean values of the physiological quality of seeds of two cultivars of carioca beans ('IAC Carioca Precoce' and 'IAC Carioca Tybatã') produced in two growing seasons (rainy and dry) under different doses of phosphorus applied in the planting furrow.

\begin{tabular}{ccccccccc}
\hline & & \multicolumn{7}{c}{ Mean squares } \\
S.V. & DF & WC & G & FGC & AA & WCAA & EC & SE \\
\hline CULTIVAR $(C T)$ & 1 & $3.81^{\text {ns }}$ & $130.66^{*}$ & $32.66^{\text {ns }}$ & $140.16^{\text {ns }}$ & $43.51^{* *}$ & $542.21^{*}$ & $128.34^{\text {ns }}$ \\
SEASONS & 1 & $4.96^{\text {ns }}$ & $816.66^{* *}$ & $3174.00^{* *}$ & $160.16^{\text {ns }}$ & $49.03^{* *}$ & $14937.81^{* *}$ & $1641.76^{* *}$ \\
DOSES & 5 & $1.14^{\text {ns }}$ & $64.26^{\text {ns }}$ & $105.06^{\text {ns }}$ & $347.50^{\text {ns }}$ & $0.91^{\text {ns }}$ & $146.87^{\text {ns }}$ & $46.43^{\text {ns }}$ \\
CT $\times$ SEASONS & 1 & $8.78^{*}$ & $266.66^{*}$ & $181.50^{\text {ns }}$ & $9760.66^{* *}$ & $11.80^{* *}$ & $132.65^{\text {ns }}$ & $297.51^{*}$ \\
CT $\times$ DOSES & 5 & $1.06^{\text {ns }}$ & $41.86^{\text {ns }}$ & $111.36^{\text {ns }}$ & $341.46^{\text {ns }}$ & $2.11^{\text {ns }}$ & $85.90^{\text {ns }}$ & $216.26^{*}$ \\
SEASON $\times$ DOSES & 5 & $0.94^{\text {ns }}$ & $62.06^{\text {ns }}$ & $133.30^{*}$ & $835.86^{*}$ & $3.04^{\text {ns }}$ & $116.57^{\text {ns }}$ & $111.83^{\text {ns }}$ \\
CT $\times$ SEAS*DOSE & 5 & $1.67^{\text {ns }}$ & $72.46^{\text {ns }}$ & $116.20^{\text {ns }}$ & $234.16^{\text {ns }}$ & $0.83^{\text {ns }}$ & $50.52^{\text {ns }}$ & $54.83^{\text {ns }}$ \\
ERROR & 72 & 1.28 & 40.16 & 53.41 & 326.13 & 1.58 & 88.05 & 70.06 \\
MEAN & - & 9.33 & 91.66 & 88.54 & 72.75 & 35.6 & 80.36 & 81.86 \\
CV $(\%)$ & - & 12.16 & 6.91 & 8.25 & 24.82 & 3.53 & 11.68 & 10.22 \\
\hline 'IAC Carioca Precoce' & & 9.13 & 92.83 & 89.12 & 73.95 & 34.95 & $77.98 \mathrm{~b}$ & 83.02 \\
'IAC Carioca Tybatã' & & 9.53 & 90.50 & 87.95 & 71.54 & 36.29 & $82.74 \mathrm{a}$ & 80.70 \\
\hline Cultivation rainy season & 9.11 & 88.75 & 82.79 & 74.04 & 34.91 & $67.89 \mathrm{~b}$ & 77.72 \\
Cultivation dry season & 9.56 & 94.58 & 94.29 & 71.45 & 36.34 & $92.83 \mathrm{a}$ & 86.00 \\
\hline
\end{tabular}

ns, ** and *: non-significant and significant at $1 \%$ and $5 \%$ significance, respectively, by the $\mathrm{F}$ test.

WC: water content; G: germination; FGC: first germination count test; AA: accelerated aging; WCAA: water content after accelerated aging; EC: Electrical conductivity, and SE: seedling emergence in the field.

The cultivar 'IAC Carioca Precoce' presented lower water content compared to the cultivar 'IAC Carioca Tybatã' in the dry season (Table 3). Among the growing seasons, there was only a difference for the cultivar 'IAC Carioca Tybatã', in which, lower water content was observed in seeds produced in the rainy season (Table 3). Despite the statistical difference between the seed water content, this did not display a variation above $1 \%$ for the tested factors, thus demonstrating reliability of the physiological quality tests, taking into account that the low oscillation between the seed water content is essential for the standardization of assessments and obtaining consistent results (MARCOS FILHO, 2015).

The germination of the cultivar 'IAC Carioca Tybatã' during the rainy season presented lower values than those for the cultivar 'IAC Carioca Precoce' (Table 3), and the seeds of the cultivar 'IAC Carioca Tybatã' produced during the rainy season, displayed lower values than those produced during the dry season. Despite these differences, all the seeds presented germination rates above $80 \%$, the minimum percentage required for the production and marketing of bean seeds (MAPA, 2013). 
Table 3. Physiological quality of seeds of two cultivars of carioca beans ('IAC Carioca Precoce' and 'IAC Carioca Tybatã') produced in two growing seasons (rainy and dry).

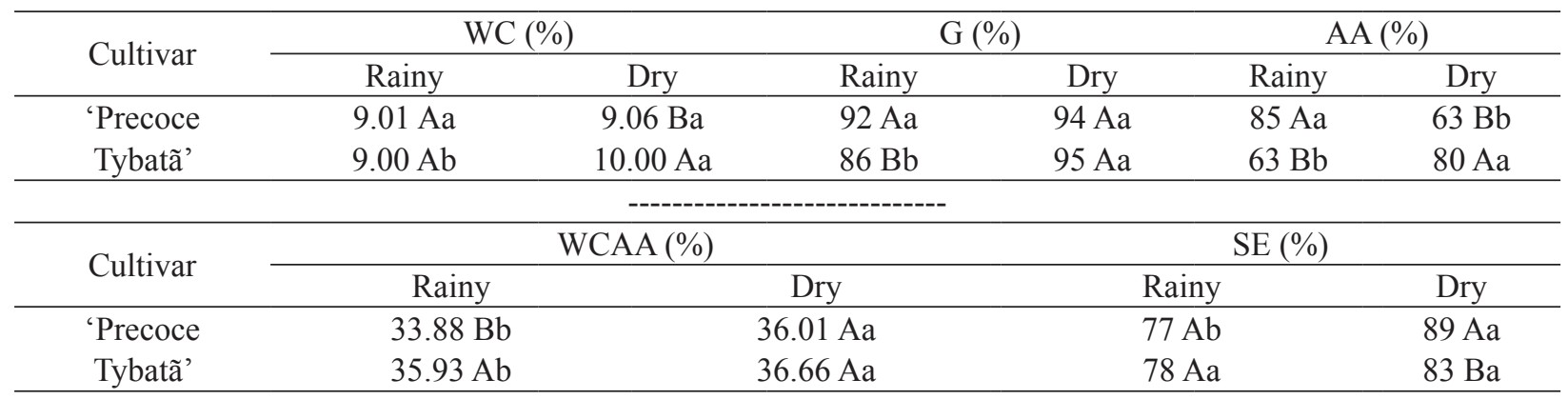

Means followed by the same letter, lowercase in the row and capitalized in the column, did not differ, by the Tukey test $(\mathrm{P} \leq 0.05)$. WC: water content; G: germination; AA: accelerated aging; WCAA: water content after accelerated aging and SE: seedling emergence in the field.

Another aspect to highlight from the results obtained in the germination test is with reference to genetic variability among cultivars and the influence of the cultivation environment, indicating that some cultivars interact more favorably with the environment than others, enabling the production of higher quality seeds (MICHELS et al., 2014). The difference between the bean cultivars and their responses to the environments for the physiological quality of seeds has also been observed in studies conducted with cowpea (DUTRA et al., 2007) and creole beans (COELHO et al., 2010).

The first germination count showed no significant interaction between growing seasons and phosphorus doses (Table 2). In the comparison between cultivation periods, seeds produced in the dry season showed greater vigor than did those produced in the rainy season (Figure 2). In response to the various doses of phosphorus, it was observed that 30 and $60 \mathrm{~kg} \mathrm{ha}^{-1}$ of $\mathrm{P}_{2} \mathrm{O}_{5}$ led to higher percentages of normal seedlings in the first germination count and, consequently, greater vigor, for the two growing seasons. The dose of maximum response was $45.5 \mathrm{~kg} \mathrm{ha}^{-1}$ and $63.2 \mathrm{~kg} \mathrm{ha}^{-1}$ for the rainy and dry seasons, respectively. Souza and
Lobato (2003) report conflicting results in relation to response to the levels of phosphorus applied to the soil, and explain that this response depends on several factors, such as the availability of phosphorus and other nutrients in the soil, the genotype chosen, and the weather conditions. Oliveira et al. (2014) evaluated the response of bean seeds of the cultivar 'IAC Carioca Tybatã' grown with two levels of phosphorus (20 and $120 \mathrm{~kg} \mathrm{ha}^{-1}$ ) and observed that when the higher dose of phosphorus was used, a larger number of seedlings were recorded in the first germination count.

In the accelerated aging test, the cultivar 'IAC Carioca Precoce' seeds produced during the rainy season displayed greater vigor, while in the dry season the cultivar 'IAC Carioca Tybatã' showed better results (Table 3). Seeds of the cultivar 'IAC Carioca Precoce', produced in the rainy season were superior to those produced in the dry season. As for the cultivar 'IAC Carioca Tybatã', the dry period led to higher values compared to the rainy season. These responses were similar to the results obtained in the germination test, where it was also observed that the cultivars showed different responses depending on the cultivation environments. 
Figure 2. First germination count of seeds from cultivars of carioca beans produced in two growing seasons (rainy and dry), under different doses of phosphorus applied in the planting furrow $\left(\mathrm{kg} \mathrm{ha}^{-1}\right.$ of $\left.\mathrm{P}_{2} \mathrm{O}_{5}\right)$.

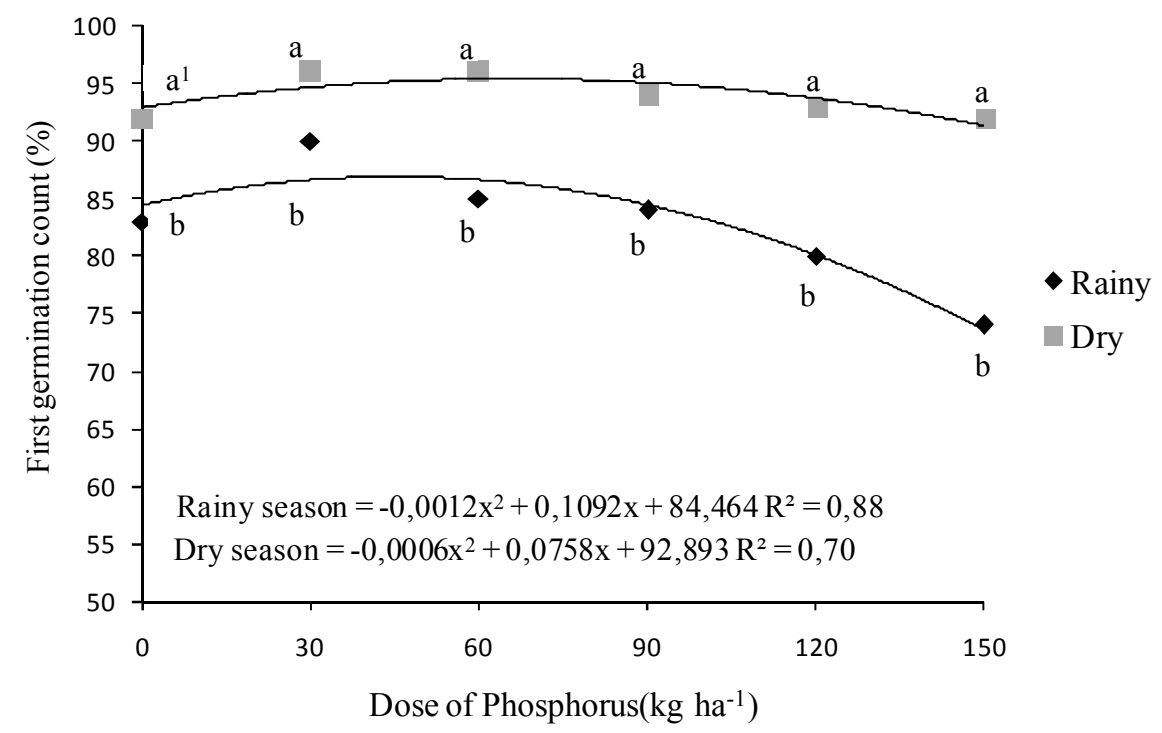

${ }^{1}$ Means followed by the same letters inside each dose of phosphorus do not differ at 0.05 probability level by Tukey test.

Moreover, in the accelerated aging test, the interaction between growing seasons and phosphorus doses revealed that the seeds produced in the dry season, under the doses 0,120 , and $150 \mathrm{~kg}$ $\mathrm{ha}^{-1}$ of $\mathrm{P}_{2} \mathrm{O}_{5}$ presented higher vigor compared to the seeds produced in the rainy season (Figure 3). For the rainy period, the behavior was quadratic, with the maximum response at $90.7 \mathrm{~kg} \mathrm{ha}^{-1}$ of phosphorus and the behavior was a linear increase for the dry period, for which it was not possible to determine the dose at which a maximum response was elicited. According to Silva et al. (2003), phosphorus is one of the main nutrients that can affect the quality of the seed (both germination and vigor). According to Guerra et al. (2006), higher concentrations of phosphorus in the soil can provide greater vigor of seeds and consequently greater initial energy for the metabolic activities of seedlings. However, this has not been verified in this study. Zucareli et al. (2006) observed that the percentage of normal seedlings after accelerated aging was greater with 30 and $60 \mathrm{~kg} \mathrm{ha}^{-1}$ of $\mathrm{P}_{2} \mathrm{O}_{5}$ for seeds of the cultivar 'IAC Carioca' cultivated during the rainy season.

For the water content after accelerated aging, the cultivar 'IAC Carioca Precoce' displayed lower values during the rainy season (Table 3), and when comparing the cultivation periods, seeds produced in the rainy season displayed lower values. The seed water content at the end of the accelerated aging test is one of the most important parameters in determining the uniformity of conditions under which the test was performed, and variations of 3 to $4 \%$ between samples are considered acceptable (MARCOS FILHO, 1999). In this study, we observed that the maximum variation was $2.78 \%$ and, thus, within the limits tolerated. Dutra and Teófilo (2007) found similar results for the water content after accelerated aging of seeds of different cultivars of cowpea grown in different cultivation years. 
Figure 3. Accelerated aging in seeds of carioca beans produced in two growing seasons (rainy and dry), under different doses of phosphorus applied in the planting furrow $\left(\mathrm{kg} \mathrm{ha}^{-1}\right.$ of $\left.\mathrm{P}_{2} \mathrm{O}_{5}\right)$.

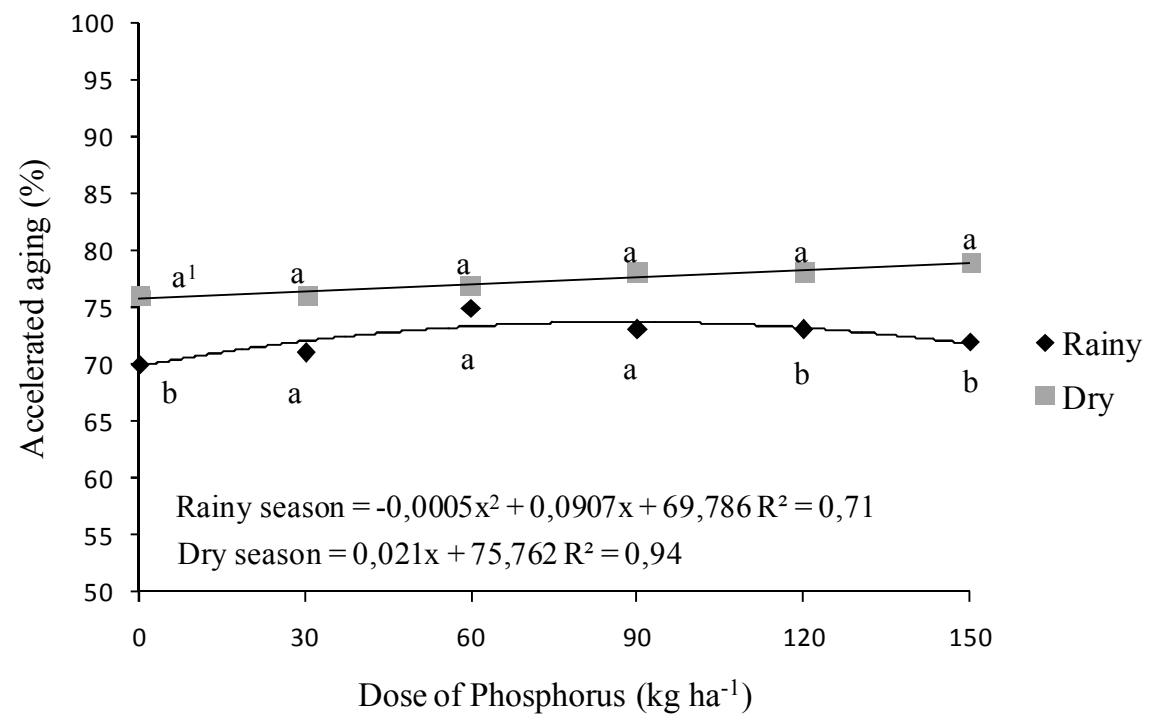

${ }^{1}$ Means followed by the same letters inside each dose of phosphorus do not differ at 0.05 probability level by Tukey test.

In the electrical conductivity test there was no interaction between the factors studied, only an isolated effect of cultivars and growing seasons was noted (Table 2). The cultivar 'IAC Carioca Precoce' displayed lower conductivity values $\left(77.98 \mu \mathrm{S} \mathrm{cm}^{-1}\right.$ $\left.\mathrm{g}^{-1}\right)$ compared to the 'IAC Carioca Tybatã' cultivar $\left(82.74 \mu \mathrm{S} \mathrm{cm} \mathrm{cm}^{-1}\right)$. These results differ from those obtained by Silva et al. (2013), who did not observe any difference in vigor, measured by the electrical conductivity, in genotypes of the carioca group. However, Vieira et al. (1996) has reported that the vigor of bean seed is strongly influenced by the genotype, when evaluated by the electrical conductivity test. For the growing seasons, the seeds produced during the rainy season presented lower values of conductivity and, therefore, less leakage of cell content compared to the dry season (Table 2). In this test, the vigor of seeds is directly related to the integrity of cell membranes, being determined by the amount of leached soluble ions present in the seed imbibitions. Thus, the greater the release of exudates in the solution, the lower is the seed vigor, i.e., greater intensity of disorganization of the cell membrane systems (CARVALHO et al., 2009; SILVA et al., 2014; VIEIRA et al., 2002).
In the dry season seedling emergence in the field was lower for the cultivar 'IAC Carioca Tybatã' compared to the cultivar 'IAC Carioca Precoce' (Table 3). When comparing the growing seasons, the highest emergence was observed for the dry season only for the cultivar 'IAC Carioca Precoce'. Michels et al. (2014) reported differences in the emergence of creole bean under field conditions, between different sites of cultivation and claim that these results may be related to the weather conditions at the time of sowing. However, they found no differences in emergence under field conditions, for the different genotypes studied. It was also possible to observe that the cultivar 'IAC Carioca Precoce' displayed a quadratic behavior with greater seedling emergence at doses of 30 and $60 \mathrm{~kg} \mathrm{ha}^{-1}$ phosphorus (Figure 4), obtaining a point of maximum response at a dose of $18.6 \mathrm{~kg} \mathrm{ha}^{-1}$. For the cultivar 'IAC Carioca Tybatã', the emergence in the field presented an increased linear behavior with the increase in the doses of phosphorus. Kikuti et al. (2006) studied the effect of the absence or presence of fertilization in 25 bean genotypes and observed that the presence of phosphorus favored the initial establishment of the crop in the field for 12 studied genotypes. 
Figure 4. Seedling emergence of seeds of two cultivars of carioca beans ('IAC Carioca Precoce' and 'IAC Carioca Tybatã') in the field produced under different doses of phosphorus applied in the planting furrow $\left(\mathrm{kg} \mathrm{ha}^{-1} \mathrm{P}_{2} \mathrm{O}_{5}\right)$.

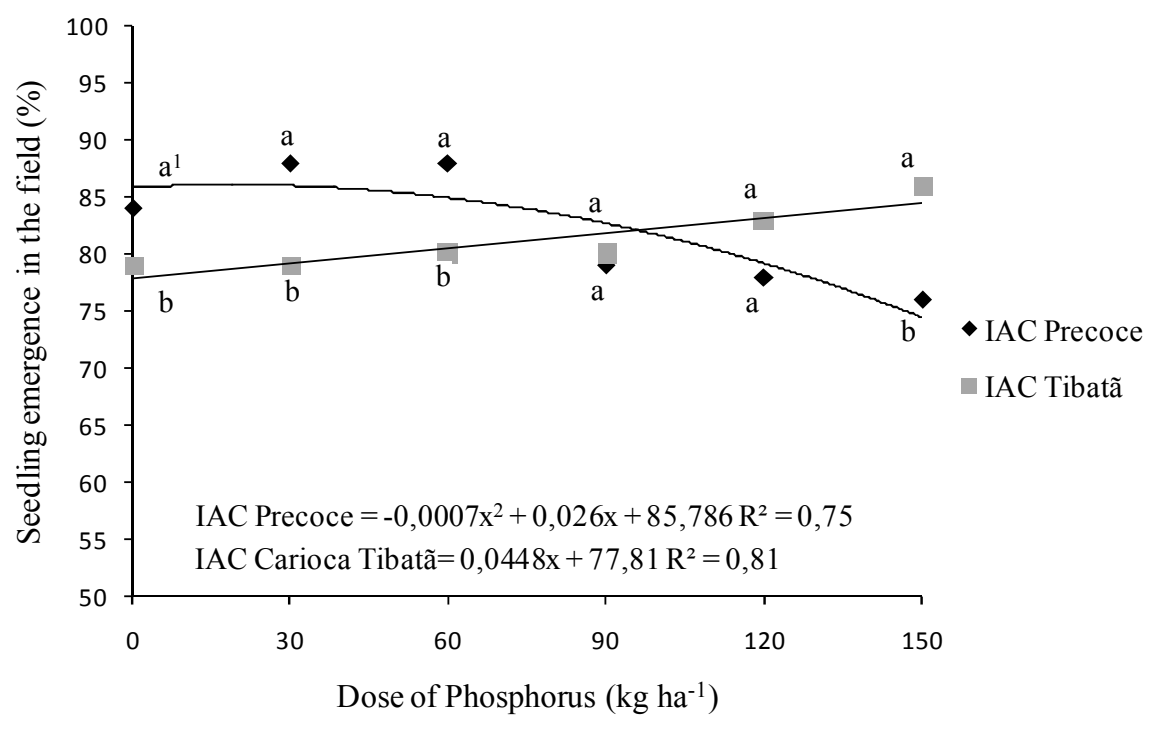

${ }^{1}$ Means followed by the same letters inside each dose of phosphorus do not differ at 0.05 probability level by Tukey test.

From the results, it was possible to observe that the cultivars have different responses regarding the physiological quality of the seeds in relation to the cultivation environments, due to their genetic characteristics. Thus, studies testing a larger number of carioca bean cultivars associated with different environments and growing seasons, and the interactions with different doses of phosphorus are necessary to obtain seeds of high physiological quality.

\section{Conclusion}

Seeds of the cultivar 'IAC Carioca Precoce' produced during the rainy season display a higher germination and greater seedling emergence in the field in the dry season compared to the cultivar 'IAC Carioca Tybatã'.

The cultivation of carioca beans in the dry season provides seeds with higher germination and vigor compared to the rainy season.

Phosphorus applied in the planting furrow favors the vigor of carioca bean seeds, measured by the accelerated aging test, with response to higher doses in dry season cultivation.

\section{Acknowledgements}

We thank Coordenação de Aperfeiçoamento de Pessoal de Nível Superior-CAPES, State University of Londrina, and Paulista State University "Júlio Mesquita Filho" for the structure and financial support for the development of the study.

\section{References}

BARBOSA, F. R.; GONZAGA, A. C. O. Informações técnicas para o cultivo do feijoeiro-comum na Região Central-Brasileira: 2012-2014. Santo Antônio de Goiás: Embrapa Arroz e Feijão, 2012. 247 p. (Documentos, 272).

BATISTELLA FILHO, F.; FERREIRA, M. E.; VIEIRA, R. D.; CRUZ, M. C. P.; CENTURION, M. A. P. C.; SYLVESTRE, T. B.; RUIZ, J. G. C. L. Adubação com fósforo e potássio para produção e qualidade de sementes de soja. Pesquisa Agropecuária Brasileira, Brasília, v. 48, n. 7, p. 783-790, 2013. 
BRASIL. Ministério da Agricultura, Pecuária e Abastecimento. Regras para análise de sementes. Ministério da Agricultura, Pecuária e Abastecimento. Secretaria de Defesa Agropecuária. Brasília, DF: Mapa/ ACS, 2009. 395 p.

CARVALHO, L. F.; SEDIYAMA, C. S.; REIS, M. S.; DIAS, D. C. F. S.; MOREIRA, M. A. Influência da temperatura de embebição da semente de soja no teste de condutividade elétrica para avaliação da qualidade fisiológica. Revista Brasileira de Sementes, Londrina, v. 31, n. 1, p. 9-17, 2009.

CARVAlHO, L. R.; MACHADO, C. G.; CRUZ, S. C. S.; RODRIGUES, J. F. Qualidade fisiológica de sementes de soja submetida a diferentes formas de aplicação de fósforo. Global Science and Technology, Rio Verde, v. 8, n. 1, p. 185-192, 2015.

CARVALHO, N. M. de; NAKAGAWA, J. (Ed.). Sementes: ciência, tecnologia e produção. Jaboticabal: FUNEP, 2012. 588 p.

CAVALCANTI-MATA, M. E. R. M.; MORAIS, J. O.; DUARTE, M. E. M.; FARIAS, P. A.; QUEIROZ, A. J. M. Cinética de congelamento do feijão (Phaseolus vulgaris L.) a baixas temperaturas. Revista Brasileira de Engenharia Agrícola e Ambiental, Campina Grande, v. 16, n. 6, p. 667-674, 2012.

COELHO, C. M. M.; MOTA, R. M.; SOUZA, C. A.; MIQUELLUTI, D. J. Potencial fisiológico em sementes de cultivares de feijão crioulo (Phaseolus vulgaris L.). Revista Brasileira de Sementes, Londrina, v. 32, n. 3, p. 097-105, 2010.

DUTRA, A. S.; BEZERRA, F. T. C.; NASCIMENTO, P. R.; LIMA, D. C. Produtividade e qualidade fisiológica de sementes de feijão caupi em função da adubação nitrogenada. Revista Ciência Agronômica, Fortaleza, v. 43, n. 4, p. 816-821, 2012.

DUTRA, A. S.; TEÓFILO, E. M. Envelhecimento acelerado para avaliar o vigor de sementes de feijão caupi. Revista Brasileira de Sementes, Londrina, v. 29, n. 1, p. 193-197, 2007.

DUTRA, A. S.; TEÓFILO, E. M.; MEDEIROS FILHO, S.; DIAS, F. T. C. Qualidade fisiológica de sementes de feijão caupi em quatro regiões do estado do Ceará. Revista Brasileira de Sementes, Londrina, v. 29, n. 1, p. 111-116, 2007.

EMPRESA BRASILEIRA DE PESQUISA AGROPECUÁRIA - EMBRAPA. Informações técnicas para o cultivo do feijoeiro-comum na Região Central-Brasileira: 2012/2014. 2012. (Documentos, 272). Disponível em: <http://www.cnpaf.embrapa.br/ transferencia/informacoestecnicas/publicacoesonline/ seriedocumentos_272.pdf $>$. Acesso em: 15 jul. 2015.
FRANÇA-NETO, J. B.; KRZYZANOWSKI, F. C.; HENNING, A. A. A importância do uso de semente de soja de alta qualidade. Informativo Abrates, Londrina, v. 20, n. 1,2, p. 37-38, 2010.

GUERRA, C. A.; MARCHETTI, M. E.; ROBAINA, A. D.; SOUZA, L. C. F.; GONÇALVES, M. C.; NOVELINO, J. O. Qualidade fisiológica de sementes de soja em função da adubação com fósforo, molibdênio e cobalto. Acta Scientiarum: Agronomy, Maringá, v. 28, n. 1, p. 91-97, 2006.

KIKUTI, H.; ANDRADE, M. J. B.; KIKUTI, A. L. P.; PEREIRA, C. E. Qualidade de sementes de genótipos de feijão em função da adubação. Revista Ciência Agronômica, Fortaleza, v. 37, n. 1, p. 37-43, 2006.

MALAVOLTA, E. Manual de nutrição mineral de plantas. São Paulo: Ceres, 2006. 638 p.

MINISTÉRIO DA AGRICULTURA, PECUÁRIA E ABASTECIMENTO - MAPA. Instrução Normativa $\mathrm{N}^{\mathrm{o}}$ 45, de 21 de setembro de 2013. Anexo XI - Padrões para produção e comercialização de sementes de feijão. (Phaseolus vulgaris L.). Disponível em: http://www.lex. com.br/legis_24861657_Instrução Normativa _N_ 45 DE 17 DE_SETEMBRO_DE 2013.aspx. Acesso em: 09 maio 2015.

MARCOS FILHO, J. Fisiologia de sementes de plantas cultivadas. Londrina: ABRATES, 2015. 660 p.

Teste de envelhecimento acelerado. In: KRZYZANOWSKI, F. C.; VIEIRA, R. D.; FRANÇA NETO, J. B. (Ed.). Vigor de sementes: conceitos e testes. Londrina: ABRATES, 1999. cap. 3, p. 3.1-3.24.

MELO FILHO, L. C.; CAMARGO, S. L.; LEITE, U. T.; LIMA, A. A. Adubação molíbdica em feijoeiro no cone sul de Rondônia. Revista Brasileira de Agrociência, Pelotas, v. 17, n. 2-4, p. 228-233, 2011.

MICHELS, A. F.; SOUZA, C. A.; COELHO, C. M. M.; ZILIO, M. Qualidade fisiológica de sementes de feijão crioulo produzidas no oeste e planalto catarinense. Revista Ciência Agronômica, Fortaleza, v. 45, n. 3, p. 620-632, 2014.

OLIVEIRA, T. C.; SILVA, J.; SALGADO, F. H. M.; BARROS, H. B.; FIDELIS, R. R. Influência do fósforo na qualidade fisiológica de sementes de feijão comum armazenadas sob condições naturais. Bioscience Journal, Uberlândia, v. 30, n. 1, p. 303-310, 2014.

RAIJ, B. V.; ANDRADE, J. C.; CANTARELLA, H.; QUAGGIO, J. A. Análise química para avaliação da fertilidade de solos tropicais. Campinas: Instituto Agronômico, 2001. 285 p. 
SALUM, J. D.; ZUCARELI, C.; GAZOLA, E.; NAKAGAWA, J. Características químicas e fisiológicas de sementes de feijão em função do teor de fósforo na semente e doses de fósforo no solo. Revista Brasileira de Sementes, Londrina, v. 30, n. 1, p. 140-149, 2008.

SANTOS, H. G. dos; JACOMINE, P. K. T.; ANJOS, L. H. C. dos; OLIVEIRA, V. A. de; OLIVEIRA, J. B. de; COELHO, M. R.; LUMBRERAS, J. F.; CUNHA, T. J. F. (Ed.). Sistema brasileiro de classificação de solos. 2. ed. Rio de Janeiro: Embrapa Solos, 2006. 306 p.

SILVA, R. J. S.; VAHL, L. C.; PESKE, S. T. Rendimento de grãos no feijoeiro em função dos teores de fósforo nas sementes. Revista Brasileira Agrociência, Pelotas, v. 9, n. 3, p. 247-250, 2003.

SILVA, S. S.; VIEIRA, R. D.; GRZYBOWSKI, C. R. S.; CARVALHO, T. C.; PANOBIANCO, M. Electrical conductivity of different common bean seeds genotypes. Journal of Seed Science, Londrina, v. 35, n. 2, p. 216224, 2013.

SILVA, V. N.; ZAMBIASI, C. A.; TILMANN, M. A. A.; MENEZES, N. L.; VILLELA, F. A. Condução do teste de condutividade elétrica utilizando partes de sementes de feijão. Revista de Ciências Agrárias, Lisboa, v. 37, n. 2, p. 206-213, 2014.

SOUZA, D. M. G.; LOBATO, L. Adubação fosfatada em solos da região do cerrado. Informações Agronômicas: POTAFÓS, n. 102, p. 1-16, 2003.

SOUZA, R. F.; FAQUIN, V.; FERNANDES, L. F.; AVILA, F. W. Nutrição fosfatada e rendimento do feijoeiro sob influência da calagem e adubação orgânica. Ciência e Agrotecnologia, Lavras, v. 30, n. 4, p. 656-664, 2006.
TOLEDO, M. Z.; FONSECA, N. R.; CESAR, M. L.; SORATTO, R. P.; CAVARIANI, C.; CRUSCIOL, C. A. C. Qualidade fisiológica e armazenamento de sementes de feijão em função da aplicação tardia de nitrogênio em cobertura. Pesquisa Agropecuária Tropical, Goiânia, v. 39, n. 2, p. 124-133, 2009.

VIEIRA, R. D.; KRZYZANOWSKI, F. C. Teste de condutividade elétrica. In: KRZYZANOWSKI, F. C.; VIEIRA, R. D.; FRANÇA NETO, J. B. Vigor de sementes: conceitos e testes. Londrina: ABRATES, 1999. p. 4.1-4.26.

VIEIRA, R. D.; PANOBIANCO, M.; LEMOS, L. B.; FORNASIERI-FILHO, D.; Efeito de genótipos de feijão e de soja sobre os resultados da condutividade elétrica de sementes. Revista Brasileira de Sementes, Brasília, v. 18, n. 2, p. 220-224, 1996.

VIEIRA, R. D.; PENARIOL, A. L.; PERECIN, D.; PANOBIANCO, M. Condutividade elétrica e teor de água inicial das sementes de soja. Pesquisa Agropecuária Brasileira, Brasília, v. 37, n. 9, p. 1333-1338, 2002.

ZUCARELI, C.; RAMOS JUNIOR, E. U.; BARREIRO, A. P.; NAKAGAWA, J.; CAVARIAN, C. Adubação fosfatada, componentes de produção, produtividade e qualidade fisiológica em sementes de feijão. Revista Brasileira de Sementes, Londrina, v. 28, n. 1, p. 5-15, 2006.

ZUCARELI, C.; PRANDO, A. M.; RAMOS JUNIOR, E. U.; NAKAGAWA, J. Fósforo na produtividade e qualidade de sementes de feijão Carioca Precoce cultivado no período das águas. Revista Ciência Agronômica, Fortaleza, v. 42, n. 1, p. 32-38, 2011. 